\section{СПИСОК ВИКОРИСТАНОЇ ЛІТЕРАТУРИ}

1. Акимов Ю. Т. Николай Иванович Ризоль / Ю. Т. Акимов // Баян и баянисты. - М. : Сов. композитор, 1981. - Вып. 5. - С. 85-110.

2. Давидов М. А. Історія виконавства на народних інструментах (українська академічна школа) / М. А. Давидов. - К. : НМАУ ім. П. І. Чайковського, 2010. -592 с.

3. Димченко С. С. Микола Різоль - легенда українського баянного мистецтва ХХ століття (до 100-річчя від дня народження) / С. С. Димченко, Т. М. Петренко // Нова педагогічна думка. - Рівне : РОІППО. 2019. - Вип. 2 (98). - С.161-164.

4. Димченко С. С. Педагогічні ідеї М. І. Різоля та ïх вплив на розвиток баянного мистецтва України / C. С. Димченко // Зб. наук. праць Кам'янець-Подільського державного університету. Серія «Педагогіка». Вип. 6. - Кам'янець-Подільський, 2005. - С. 149-154.

5. Інструментальна музика XVII - першої половини XVIII ст. URL: https://studme.com. ua/1725032513604/kulturologiya/instrumentalnaya muzyka_xvii_pervoy_poloviny_xviii.htm (дата звернення: 10.10.2019).

6. Кужелев Д. О. Баянна творчість українських композиторів : навч. посіб. / Д. О. Кужелев. - Л. : СПОЛОМ, 2011. - 206 с.
7. Кузнецов В. Ф. Концерты и сонаты для баяна / В. Ф. Кузнецов. - К. : Музична Украина, 1990. - 149 с.

8. Нижник А. А. Український баянний концерт 1970-х років: тенденції розвитку жанру / А. А. Нижник // Музичне мистецтво. Вип. 9. - ДДМА ім. С. С. Прокоф'єва, ЛНМА ім. М. В. Лисенка. - Донецьк-Львів: Юго-Восток. - 2009. - С. 133-141.

9. Семешко А. А. Баянно-акордеонне мистецтво України на зламі XX-XXI століть: бібліографічний довідник/ А. А. Семешко. - Тернопіль, навчальна книга - Богдан, 2009. - 214 с.

10. Сташевський А. Я. Нариси 3 історії української музики для баяна: навчальний посібник / А. Я. Сташевський. - Луганськ: Поліграфресурс, 2006. - $152 \mathrm{c}$

11. Сташевський А. Я. Великі жанри в українській музиці для баяна (тенденції розвитку в останній чверті XX на початку XXI ст.) / А. Я. Сташевський. - Луганськ : Поліграфресурс, 2007. - 159 с.

12. Чумак Ю. В. Концертні жанри в баянній творчості українських композиторів (на прикладі Концерту для баяна № 1 В. Власова) / Ю. В.Чумак // Науковий вісник НМАУ ім. П. І. Чайковського: виконавське музикознавство. - К. : НМАУ ім. П. І. Чайковського, 2013. - Вип. 107. - С. 176-177.

Дата надходження до редакиї: 22.11.2019 р.

Богдан ЖУЛкОВСький, кандидат мистеитвознавства, викладач вищої категорії, голова Регіональної ради молодих вчених при управлінні освіти, науки та молоді Волинської обласної державної адміністраиії

\title{
ГАЛИЦЬКА ТА КАРПАТО-РУСЬКА ТРАДИЦЇ̈ ЦЕРКОВНО-МОНОДІЙНОГО СПІВУ ХІХ СТОЛІТТЯ (на прикладі монострофних кондаків)
}

У статті окреслено ознаки значно більшої архаїчності карпато-руських гімнів порівняно з галицькими. Класифіковано музичні структури кондаків. Встановлено, щзо аналогічні форми були характерні для ранньовізантійських тропарів.

Ключові слова: богослужбовий монодійний спів, монострофний кондак, гімнографія, галищька традииія, карпато-руська традиція.

В статье отмечень признаки значительно большей архаичности карпато-русских гимнов по сравнению с галиикими. Классифицированы музыкальные структуры кондаков. Установлено, что эти формы были характерны для ранневизантийских тропарей.
Ключевые слова: иерковно-монодическое пение, монострофный кондак, гимнография, галицккая традиция, карпато-русская традиция.

The article deals with the musical features of 19th-century Western Ukrainian kontakions, which allows to differentiate Galician and Carpathian-Russian singing areas. The poetic basis of the kontakions of both these traditions is common (except for minor variations) and is a canonical version of Nikon. However, from the point of view of the musical component, the difference is observed - the Carpathian-Russian tradition is more archaic: it preserves separate chants of a small significant chant (noted by Stephan Reynolds, Joan Roccasalvo), 
specific falsification, mismatch of long sounds. The Galician tradition, though ahead of the Carpathian-Russian time of compilation, shows more modern musical style. But the similarity of some melotypes shows that the traditions are partly related, and there were intra-church connections.

The similarity (though not the identity) of the compositional structures of Sunday kontakions and troparions of the Galician and Carpathian-Russian traditions is noted. The musical analysis of the kontakions of the second half of the 19th - beginning of the 20th centuries shows the existence of a typology of compositional structures common to all troparion genres: 1) one-line (series); 2) two-row (arsis / thesis); 3) with one or two additional melodies, mainly in code (available in forms with different number of key melodies). Comparison with the results of Byzantine kontakion studies by German musicologist and byzantologist Constantin Floros reveals that the Galician and Carpathian-Russian samples retain the principles of formation characteristic for Byzantine troparion hymns.

Key words: liturgical monody singing, monostrophic kontakion, hymnography, Galician tradition, Carpathian-Russian tradition.

Постановка проблеми. Традиція одноголосного виконання піснеспівів на богослужіннях зберігалася на теренах Західної України здавна (до ХІХ ст. включно), а в деяких периферійних храмах існує й дотепер. XIX ст. відзначилося поглибленням інтересу до автентичного церковного співу з боку як дяків, так і священників. Активізувало цей процес відкриття наприкінці XVIII ст. Львівської греко-католицької духовної семінарії та Ставропігійського інституту, згодом - Перемишльського дяко-вчительського інституту, школи дяків у Станіславові та інших священницьких і дяківських освітніх осередків. У другій половині XIX ст. продовжували складати невеликі навчальні посібники з теорії церковного співу, зокрема «Алфавіт ірмологісанія» Симеона Рибака (ЛННБ ${ }^{1}$. MB 28. Арк. 1зв. - 4зв.: вкл.), «Наука ірмологійного співу» Петра Любовича (ЛННБ. НД 204/2), «Наука о церковном пьнії» Дмитра Якубовича (ЛННБ. НД 207), а також «Наука о сольках» Порфирія Бажанського (ЛННБ. НД 204) [1]

Поряд 3 історичними та теоретичними працями 3'явилися нотні співацькі антології під різними назвами: «Гласопьснець» (рукописи: 1839 р., ІЛ НАНУ². Ф. 3. № 4782; другої чверті ХІХ ст., НМЛ. F 663; друки: Львів, 1847, 1870, 1894 (упорядник Ісидор Дольницький), 1905; Рим, 1881, 1951; Вінніпег, 1955; Івано-Франківськ, 1999 тощо), «Напъвник Церковный» (Перемишль, 1902; Рим, 1952, 1959 тощо) та «Простопьніе» (Унгвар, 1906; Мукачево, 1930; Вілкс-Беpi, 1925; Загреб, 1944; Пряшів, 1948; Пряшів, 1978 - під назвою «Пћснословъ»; Пітсбург, 1982 тощо). Вочевидь, такі книги були зручними для практичного вжитку, тому їх видання продовжилося й у XX ст., що розширює базу текстологічних порівнянь і дає можливість виявити ступінь тяглості співацьких традицій.

Відповідно до походження піснеспівів класифікуємо ці збірники за двома локальними традиціями Західної України XIX ст.: галицька - «Гласопъснець» і «Напъвник Церковный»; карпато-руська - «ПростопЊніе».
Окремим виданням $є$ «Псалтихія или Пњснослов» (Львів, 1896), укладена кліриком Львівського храму ієромонахом Свгенієм-Еммануїлом Воробкевичем, сином композитора та письменника Ісидора Воробкевича (1836-1903). Позаяк цей збірник не містить кондаків, далі його не розглядаємо.

Аналіз наукових досліджень і публікацій. Церковний монодійний спів Галичини XIX ст. досліджували українські музикознавці Ісидор Дольницький, Ігнатій Полотнюк, Порфирій Бажанський, Борис Кудрик, Мирослав Антонович, Юрій Ясіновський, Наталія Костюк, Зорина Валіхновська, Леся Мороз. Усна та писемна традиції літургічної музики Закарпаття цього періоду стали предметом наукових студій Іоанна Бокшая, Федора Стешка, Егона Веллеса, Івана Гарднера, Стефана Рейнольдса, Джоан Роккасальво, Ігоря Задорожного, Федора Копинця, Олексія Тулюка. Значна увага авторів означених наукових праць приділяється питанням компаративістики київської, галицької та карпато-руської монодійної спадщини. Чимало дослідників убачають консеквентність західноукраїнського літургічного співу XIX ст. від візантійсько-руських витоків.

Мета статті - реконструювати репертуар, класифікувати форми та охарактеризувати стилістичні елементи кондаків за західноукраїнськими співацькими антологіями середини XIX - початку XX ст.; на прикладі кондаків окреслити низку подібностей $\mathrm{i}$ відмінностей між двома церковно-монодійними традиціями - галицькою та карпато-руською.

Виклад основного матеріалу. Галицьку традицію в аспекті хронології представлено першими в Західній Україні рукописними нотними збірниками не ірмолойного типу - «Гласопъснцями» (на сьогодні відомо про два рукописні їх примірники: ІЛ НАНУ. Ф. 3. № 4782; НМЛ³. F 663). Вони включали обмежений репертуар гімнографічних творів: прокимни, тропарі та деякі кондаки недільні восьми гласів, подобні стихир, вибрані піснеспіви тріодного кола, «Всенощного Бдънія», гімни Літургії Іоанна Златоуста і Василія Великого.

Друковані «Гласопьснці» (зокрема 1847 та 1894 pp.) також могли містити сідальни, степенні антифони, ірмоси, догматики, незмінні піснеспіви Повечір'я, Літургії Передосвячених Дарів (Григорія Двоєслова). Рукописні «Гласопъснці» містять київську п'ятилінійну квадратну нотацію, друковані - ромбічну, котра аналогічна західноєвропейській пізній мензуральній нотації.

Подібний до «Гласопъснців» за наповненням та стилістикою «Напђвник Церковный» Ігнатія Полотнюка (Перемишль, 1902), до якого увійшла більшість піснеспівів - Вечірні, Утрені, окремі піснеспіви Тріоді Постової та Цвітної. Серед осмогласних жанрів тут представлено подобні стихир (руського і болгарського наспівів), прокимни, стихири, сідальни, тропарі й деякі кондаки. На відміну від «Гласопъснця» «Напьвник» має італійську круглу нотацію.

Спільною особливістю «Гласопьснців» та «Напъвника» є наявність у них недільних кондаків 3-го, 4-го, 6-го та 8-го гласів, які мають оригінальні мелодії, відмінні від тропарів. Натомість кондаки 1-го, 2-го, 5-го і 7-го гласів указано (відповідно до лемм у цих книгах) виконувати за моделями недільних тропарів.

${ }^{1}$ ЛННБ - Львівська національна наукова бібліотека ім. В. Стефаника

2 ІЛ НАНУ - архів Інституту літератури ім. Т. Г. Шевченка Національної академії наук Украӥни, Київ

НМЛ - Начіональний музей у Львові ім. А. Шептииького 
Така традиція пізня - ймовірно ХІХ ст. Причина наявності у «Гласопъснцях» і «Напъвниках» не всіх недільних кондаків, а лише окремих гласів, пояснюється, на нашу думку, широким використанням кондаків 3-го, 4-го, 6-го, 8-го гласів у співацькій традиції, починаючи з візантійської доби, що відтворено в слов'яно-руських Кондакарях, українських та білоруських нотолінійних Ірмологіонах, ненотованих Анфологіонах, Тріодях Постових та Цвітних.

Натомість відповідно до давніх джерел (Студійського та Єрусалимського Типіконів, візантійських Псалтиконів) майже всі недільні кондаки мають бути розспівані за моделями не тропарів, а мінейних і тріодних кондаків. Винятком є кондак 5-го гласу, створений за моделлю недільного тропаря цього гласу, адже мелодичної моделі кондака 5-го гласу, мабуть, не існувало.

Музично-стильовий аналіз усіх недільних кондаків подано у четвертому розділі нашої дисертації [2, с. 153-162]. У цій публікації пропонуємо короткий аналіз єдиного зразка - недільного кондака 8-го гласу. Опорні тони у знайдених наспівах прочитуємо подвійно - за реальною тональністю нотного прикладу (із двома бемолями при ключі) і згідно з альтовим ключем С (поданий мелодичний рельєф прочитується без змін, але бемолі не враховуються).

Недільний кондак 8-го гласу «Воскресь изъ Гроба» належить виконувати «на подобен» кондака всім святим «Яко начатки естества». Відсутність його в нотолінійних Ірмологіонах не дозволила порівняти цей зразок із його моделлю, тому було проведено зіставлення 3 іншими поширеними кондаками 8-го гласу (Пасхи «Аще и въ Гробъ», Богородиці - «Възбранной»).

Наспів недільного кондака 8-го гласу з «Напьвника» Ігнатія Полотнюка характеризується обмеженим діапазоном ( $\mathrm{a}-\mathrm{d}_{1}$; тобто $\mathrm{h}-\mathrm{e}_{1}$ в традиційному запису). Висхідні інтонації в межах малої терції виконують зображальну роль, будучи пов'язаними $з$ теологічним змістом розспівуваних слів («воздвиглъ», «воскресилъ», «воскресенїи»), симетричний низхідний хід виконує синтаксичну роль кадансування. Визначальну роль у наспіві відіграють три опорні тони: с (ініціальний, рецитація), b (рецитація), а (фінальний) $\left(\mathrm{d}_{1}, \mathrm{c}_{1}, \mathrm{~h}\right)$.

Кондак 8-го гласу 3 двох «Гласопьснців» (рукописного 1839 р., ІЛ НАНУ. Ф. 3. № 4782. Арк. 5 - 5 зв., і друкованого 1847 р.) має форму АВАВАВАВАВ $\mathrm{C}_{1}$. Між їх словесними текстами $є$ редакційні відмінності: «смерти державу стерль еси» (1839 р.) - «Адама воскресил еси» (1847 р.). Остання наявна в канонічному тексті Октоїха та зберігається в подальших «Гласопьснцях» і «Напъвниках». Перша версія не трапляється в жодному джерелі (рукописі та друку), тому іï можна вважати помилкою переписувача. Також у цій версії трапився інший огріх автора книги: «мертвїи концы» замість «мїрстіи концы».

Музична форма недільного кондака 8-го гласу 3 «Гласопьснця» 1894 р. (і «Напьвника» 1959 р.) ABAВАВАВАВС; між версіями $є$ незначні мелодичні різночитання. Іншу редакцію форми, що відображає зменшення обсягів гімну, знаходимо у версії з «Напъвника» 1902 р.: АВАВАВ AB $_{2}$ (виникла за рахунок поєднання останніх п'яти вербальних колонів у два музичних: 2+3). Стиснення пояснюється впливом усної традиції. За мелодикою редакція 1902 р. наслідує недільний кондак 8-го гласу 3 «Гласопьснців» 1847 та 1894 pp.
«Гласопъснці» містили й деякі інші кондаки, репертуар яких варіювався в кожній антології. До збірника 1839 р. (ІЛ НАНУ. Ф. 3, 4782) входять кондаки Різдва Христового й Богоявлення (арк. 58-58 зв.; арк. 24 зв.; останній записано в розділі «Подобнів»). До першого друкованого «Гласопьснця» і «Гласопъснця малого» включено кондак Різдва Христового «Дьва^ днесь», до примірника 1894 р. - заупокійний «Со свАтыми оупокой». До «Напъвника» 1902 р. увійшли кондаки Великого акафіста «Възбранной» (із ремаркою щодо виконання в кінці Утрені) та Великого канону «Душе моА» (його наспів узято 3 «Богоговъйнихъ пъсней», Почаїв, 1806). Обидва кондаки мають мелодії, неідентичні недільним гімнам. Мелодія першого нагадує другий голос акордового чотириголосся чи триголосся (кантовість), другого - має паралітургічну генезу.

Оригінальний наспів має пасхальний кондак «Аще и во Гробъ» 8-го гласу з «Напьвника» 1902 р. Форма спрощена (АВАВА $\mathrm{B})$ порівняно 3 недільним, що можна пояснити меншою кількістю поетичних колонів. За деякої інтонаційної схожості спрощену форму ( $\left.\mathrm{AAA}_{1} \mathrm{~A}_{2} \mathrm{~A}_{1} \mathrm{~B}\right)$ має кондак зі збірника Івана Кипріяна «Оутреня въ СвАтую и Великую Недђлю Пасхи» (Львів, 1883).

Аналізуючи продовження традиції, додамо, що «Напъвник» 1959 р., окрім недільних, містить 1-й і 13-й кондаки Великого акафіста, варіанти приспівів до ікосів цього ж гімну, закінчення ікоса Воскресіння Христового та заупокійний кондак. Останній не зберіг оригінального наспіву 8-го гласу.

Карпато-руську традицію відображають друковані нотні книги 3 назвою «Простопьніе», перший 3 яких (Ужгород, 1906) записаний Іоанном Бокшаєм iз голосу Іосифа Малинича. «Простопьніє» стало спільною традицією для кількох уніатських і деяких православних єпархій, зокрема Мукачівської, Пряшівської, Гайдудорозької, Крижевацької; Кошицького та Празького екзархатів (а також Пітсбурзької митрополії). Подібні антології видавали у XX ст. і на українських землях, і поза ними: 1906 р. - у Будапешті (Іоанн Бокшай), 1930 р. - у Мукачево (Іоаким Хома), 1944 р. - у Загребі (Інокентій Тимко). Три видання «Простопьнія» здійснено в Пряшеві: 1948 р. (Іоанн Кочан), 1970 р. (Стефан Папп; самоназва «Ірмологіон»), 1978 р. (Георгій Бобак; самоназва -

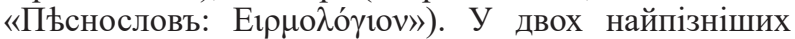
виданнях (Стефан Папп, Георгій Бобак) до збірника іншого типу бачимо вживання історичної назви «ррмологіон».

Антології карпато-руської традиції містять воскресні кондаки 3-го, 4-го, 6-го і 8-го гласів 3 оригінальними наспівами (не тропарними). У «Простопьнії» 1948 р. і «Пъснослові» 1978 р. викладено також наспіви кондаків 1-го, 2-го, 5-го і 7-го гласів, створених за моделями тропарів. Музичний аналіз усіх недільних кондаків міститься на сторінках нашої кандидатської дисертації [2, с. 164-170]. У цій статті подаємо аналіз воскресного кондака 8-го гласу.

Наспів кондака 3 «Простопънія» 1906 р. має діапазон зменшеної квінти (a- es $)$ як і в тропарі 7-го гласу 3 галицького «Напъвника» Ігнатія Полотнюка, де еs вжито в оспівувальному русі до вершини тетрахорду $-\mathrm{d}_{1}$. Для непарних рядків характерна висхідна спрямованість, пов’язана 3 догматом Воскресіння («Воскреслъ», «воздвиглъ», «Воскресенїи», «востаніемъ»). 
Натомість низхідна природа парних рядків пов'язана 3 радістю від Воскресіння («и мірстїи концы торжествуютъ»). Музична складова іноді порушує логіку наголосів вербального тексту, прийняту після реформ патріарха Никона. Основну функцію в наспіві грають опорні тони a, $\mathrm{d}_{1}$ (ініціальні, заключні), $\mathrm{c}_{1}$ (рецитація).

Музична форма розглянутого кондака (АВАВАВ) зберігається в пізніших карпато-руських антологіях. Обсяги цього гімну з галицьких нотних збірників дещо розширені (наприклад, у «Напъвнику» Ігнатія Полотнюка - $\mathrm{AB} \mathrm{AB}_{\mathrm{AB}} \mathrm{AB}_{2}$, у «Гласопьснці» Ісидора Дольницького - АВАВАВАВАВС).

3 інших кондаків у карпато-руських «Простопьніях» часто трапляються пасхальний «Аще и во Гробъ», заупокійний «Со свАтыми оупокой» та Великого канону «Душе мо^», рідше - різдвяний «Дьва^ днесь», Богородичні «Заступнице христїанъ» $\mathrm{i}$ «Не имамы ины^ помощи». Деякі нотні збірники містять приспіви до акафіста Богородиці, акафіста Ісусу Сладчайшому та експліцит до кондака Великої суботи.

Кондаки 8-го гласу «Аще и во Гробъ» і «Со свАтыми оупокой» $є$ подобнами і зберігають оригінальний наспів недільного кондака 8-го гласу як самоподобна. Перший із них зберігає також його музичну форму: ABA BA В. Будова заупокійного кондака, як і його обсяг, такого ж типу, але на два мелодичні рядки менша: ABA B. Наспіви кондаків 8-го гласу 3 «Простопінія» записано в різних «тональностях», що відображає їх зміст. Пасхальний «Аще и во Гробъ» зафіксовано великою секундою вище, ніж «Воскресль из Гроба», а поховальний «Со свАтыми оупокой» - чистою квартою нижче. Заупокійний кондак повинен звучати «мрачно», недільний - «свБтло», пасхальний «тресвђтло». Відповідно до Типікону, пасхальний і заупокійний кондаки є самогласними, тобто повинні мати оригінальні наспіви. Вочевидь, уставні рубрики щодо цього у співацькій практиці Західної України XIX - XX ст. не було збережено.

Висновки. Аналіз музичних особливостей західноукраїнських кондаків XIX ст. дає змогу чітко диференціювати галицький i карпато-руський церковно-співацькі ареали. Активне поширення усної практики передачі наспівів сприяло виникненню місцевих версій піснеспівів, серед яких особливо виокремлюються дві означені локальні традиції. Текстова основа кондаків обох розглянутих практик $\epsilon$ спільною (хоч іноді $є$ різночитання) і становить собою никонівську редакцію. Утім із погляду музичної складової спостережено різницю:

- карпато-руська традиція загалом більш архаїчна порівняно з галицькою (специфічні ладові звороти, «неправильне» узгодження вербальних та музичних акцентів: незбіжність довгих звуків та наголошених складів). При цьому американськими дослідниками Стефаном Рейнольдсом [4] та Джоан Роккасальво [5] висловлено гіпотезу стосовно карпато-руських піснеспівів інших жанрів - про збережені в них деякі поспівкові формули малого знаменного розспіву;

- галицька традиція, хоча й випереджує карпато-руську за хронологією формування збірників, демонструє модернішу стилістику.

Нами було встановлено, що і галицькій, і карпато-руській традиції властивий вільний несиметричний ритм рецитації та короткі мелодичні звороти псалмодійно-формульного типу. Помітною $\epsilon$ схожість галицьких і карпато-руських версій, яка простежується на різних рівнях: ритміка, мелодика, ладова конструкція гласових опор (нотованих у різних «тональностях»), форма. Це може свідчити про їхній спільний архетип, котрий сягає значно давніших часів, ніж середина XIX ст.

Відзначено подібність (проте не тотожність) музичних форм воскресних кондаків і тропарів XIX ст. галицької і карпато-руської локацій. Аналіз засвідчує існування типології, спільної для тропарних жанрів, продемонстрованої вже у XVII - XVIII ст. піснеспівами 3 нотолінійних Ірмологіонів:

1) однорядкові форми або серіації;

2) дворядкові форми типу «арсис - тезис»;

3) строфи 3 «кодами» - «додатковими» одним, рідше - двома мелорядками (спостерігаються в структурах із різною кількістю ключових мелорядків).

Означені структури зберігають принципи формотворення, типові вже для ранньовізантійської доби. Прикладом слугує відомий факт, описаний у «Житії» преподобного Авксентія Вифінського. Подібні піснеспіви писав і преподобний Єфрем Сирін. Припускаємо, що виконання тропарних гімнів зберегло впродовж багатьох століть архаїчні ознаки, наслідуючи генетичні особливості тропаря як одного із найстарших візантійських богослужбових жанрів.

Поява книг iз самоназвами «Гласопъснець», «Напьвник», «Простопьніе», «Пъснослов» мала на меті фіксацію та уніфікацію існуючих наспівів місцевих традицій. Історична місія таких антологій полягала в збереженні локальних версій монодійних гімнів, які піддавалися чужоземним впливам («ополячення» в Галичині, «мадяризація» на Закарпатті). Ці збірники і сьогодні слугують джерелами церковномонодійної традиції не лише в уніатських і православних парафіях України, а й в окремих єпархіях Європи та США.

\section{СПИСОК ВИКОРИСТАНОЇ ЛІТЕРАТУРИ}

1. Валіхновська 3. О. Музично-церковна освіта Галичини австрійської доби (1772-1918) : дис. ... канд. мистецтвознавства : 17.00.03 «Музичне мистецтво» / Зорина Олегівна Валіхновська ; Прикарпатський національний університет імені Василя Стефаника. - Івано-Франківськ, 2009. - 173 с.

2. Жулковський Б. С. Жанр кондака в українському церковно-монодійному співі XV - XIX століть : дис. ... канд. мистецтвознавства : 17.00 .03 «Музичне мистецтво» / Богдан Свгенович Жулковський ; Національна музична академія України імені П. І. Чайковського. - К., 2015. - 213 с.

3. Жулковський Б. Кондак як гімнографічний жанр: літургічні та музикознавчі аспекти / Б. Жулковський // Науковий вісник Національної музичної академії України імені П. І. Чайковського. - К., 2014. Вип. 109. - С. 12-33.

4. Reynolds S. The Lesser Znamennyj and Kiev Chants their Carpathion Counterparts : The Stichiry Samohlasnyja / Stephan Reynolds // A Thesis ... Doctor of Philosophy (Musicology). - Origon, [б. д.]. - 185 p.

5. Roccasalvo J. L. The Plainchant Tradition of Southwestern Rus` : Kiev - Lviv - Subcarpathian Rus` / Joan Roccasalvo // A Thesis ... Doctor of Philosophy (Musicology). - Washington, 1985. - 185 p.

Дата надходження до редакиї: 20.01.2020 р. 